\title{
FORUM
}

\section{An Overview of Proximate Factors Affecting the Nesting Behavior of Solitary Wasps and Bees (Hymenoptera: Aculeata) in Preexisting Cavities in Wood}

\author{
Elder F. Morato ${ }^{1}$ and Rogério P. Martins ${ }^{2}$ \\ ${ }^{1}$ Depto. Ciências da Natureza, Universidade Federal do Acre, Campus, 69915-900, Rio Branco, AC \\ elderfmorato@yahoo.com.br \\ ${ }^{2}$ Depto. Biologia Geral, Univ. Federal de Minas Gerais, 30161-970, Belo Horizonte, MG, wasp@mono.icb.ufmg.br
}

Neotropical Entomology 35(3):285-298 (2006)

Revisão sobre a Influência de Fatores Proximais na Nidificação de Vespas e Abelhas Solitárias (Hymenoptera: Aculeata) em Cavidades Pré-Existentes no Lenho

\begin{abstract}
RESUMO - Espécies de vespas e abelhas solitárias que nidificam em cavidades pré-existentes no lenho de plantas integram uma guilda de nidificação e são importantes componentes da maioria dos ecossistemas terrestres. Isso se deve, em parte, ao grande número de interações (e.g. predação e polinização) que mantêm com outras espécies de organismos. Variações espaciais e temporais em sua abundância e riqueza podem estar correlacionadas a alterações na estrutura do ambiente. Uma fase crítica no ciclo de vida de vespas e abelhas solitárias é o período de nidificação. As fêmeas dessas espécies investem a maior parte de seu tempo de vida em construir e aprovisionar seus ninhos. Ao contrário do que ocorre para espécies que nidificam no solo ou fazem seus ninhos expostos, até o momento não houve tentativa alguma de discutir o conjunto de fatores que influenciam o sucesso de nidificação das espécies que nidificam em cavidades pré-existentes no lenho de plantas. Este artigo revê aspectos que afetam a nidificação desses Aculeata, com ênfase em fatores proximais, tais como a disponibilidade e características de cavidades no lenho. Compreender como esses fatores agem sobre a sobrevivência e o sucesso reprodutivo é de grande importância para a conservação e manejo dessas espécies.
\end{abstract}

PALAVRAS-CHAVE: Vespa solitária, abelha solitária, guilda, cavidade em árvores, ninho-armadilha

\begin{abstract}
Guilds of Aculeate solitary wasps and bees that nest in preexisting cavities in wood are important components of terrestrial ecosystems because they engage in several ecological interactions (e.g. predation and pollination) with other species of plants and animals. Spatial and temporal variations in richness and abundance of solitary wasps and bees can be related to changes in environmental structure and in the diversity of other groups of organisms. The nesting period of these Aculeata is their most critical life cycle stage. Females of solitary wasp and bee species invest relatively more time constructing and provisioning their nests than do females of social species. Differently from species that nest in the soil or construct exposed nests, the main factors affecting the reproductive success of solitary species nesting in preexisting wood holes are still unknown. Our objective is to provide an overview of the role of proximate causes of nesting failure or success among solitary wasps and bees (Aculeata), for designing effective conservation and management strategies for these Hymenoptera.
\end{abstract}

KEY WORDS: Solitary wasp, solitary bee, guild, tree hole, trap-nest

Environmental physical structures certainly affect the reproductive success of solitary wasps and bees, the nesting period being a critical phase in their life cycle. Differently from Aculeata eusocial species, solitary wasps and bees spend most of their lifetime constructing and provisioning their nests. The factors affecting these activities, such as nest-site and food availability are, in turn, affected by the environmental structure.

Nest construction and provision prior to egg-laying is the way females of many non-parasitic species of solitary 
Aculeata invest in their offspring. This adaptive nesting behavior increases the chances of offspring survival until they reach the reproduction stage (Wilson 1971, 1975; O'Neill 2001). In spite of female adaptive behavior, species that nest in preexisting holes are usually less fertile than females of other insect species (Engelmann 1970, Michener 1974, O’Neill 2001).

Structural nest features among the Aculeata species are variable but all nests have a "cell" (Michener 1974). Cell inner space dimensions are similar for adult male or female insects belonging to the nesting species (Michener 1974). Starting with egg posture, the immature develop inside the cell. The shape and number of cells in a nest vary widely among and within species (Roubik 1989). In this study, the main proximate factors affecting nesting success of woodnesting solitary wasps and bees are reported for the first time.

\section{Origin and Availability of Cavities in Wood}

Environmental factors such as winds and rainfall, and the activities of vertebrates, invertebrates, fungi, and bacteria produce cavities in wood. For instance, the action of boring beetles Anobiidae, Brentidae, Platypodidae, Scolytidae and Buprestidae and the larvae of some Lepidoptera and Diptera results in galleries and cavities burrowed in trunks and twigs of live and dead trees (Wilson 1971, Daly et al. 1978, Berryman 1986, Borror et al. 1992, Hill 1997, Abreu et al. 2002, Dorval et al. 2004). In the humid tropical forests, several kinds of cavities and hollows of different origins and sizes are built in live and dead tree trunks (Fig. 1a-c). Some species of fungi produce cavities whereas others proliferate inside them (Fig. 1d) or externally, on wood surface (Fig. 1e).

Several factors can affect the availability of cavities in wood (Newton 1994, Apetorgbor et al. 2004). Independently of vegetation physiognomy and structure, the number of cavities increases with the age of trees; aging increases the amount of rotten wood available for the action of physical and biological agents (Moorman et al. 1999). Eventually, forest senescence can reach an equilibrium, where the rate of cavity increase is compensated by the rate of cavity decrease due to the falling of trees and their further deterioration by the natural closing and filling of cavities by debris and organic matter. Undisturbed forests normally have more standing dead trees, potential sources of cavities for animals, than disturbed forests do.

In temperate forests, the greater the biomass or volume of a tree, the longer it stands in deterioration (Newton 1994, Moorman et al. 1999, Ganey \& Vojta 2004, Spiering \& Knight 2005).Therefore, the variability of cavity sizes and animals that explore these trees is greater. In periodically disturbed environments (e.g. more localized and less intense burnings, lopping of trees and branches, cutting of small trees), the availability of cavities should be greater (Ganey $\&$ Vojta 2004). However, very intense forest perturbation diminishes the availability of natural cavities because many trees die when still very young.

Timber physical properties and anatomical characteristics vary widely according to tree species (see Forest Products Laboratory 1974, Burger \& Richter 1991, Rizzini 1995, Souza 2002) (Fig. 2). Timber traits are partially determined by the local ecological conditions such as water availability, and edaphic and climatic factors (Metcalf \& Chalk 1983). Some tree species are more prone to develop cavities and hollows than others (Fig. 3), due to variations in the degree of resistance to fire, timber durability and hardness, proneness to gall formation and branching, or even the resistance to physical and biochemical processes that lead to wood rotting and decomposition (Gibbons \& Lindenmayer 1996, Jesus et al. 1998, Paes et al. 2004).

The longer the branches and twigs are exposed to direct sunlight, the more prone they will be to develop cavities and hollows. However, these substrates are extremely unstable and can fall by the action of gravity or wind (Roubik 1989). Trees with many cavities and hollows are more prone to the destructive effects of fire and wind (Lindenmayer et al. 1991).

A tree goes through successive stages of senescence and proneness to physical decline (Gibbons \& Lindenmayer 1996). In each stage, cavities and hollows can be available for different animal species. Thus, it is not wrong to say that trees at different ages and stages of physical deterioration are occupied and utilized by different animals.

Large-trunk tree species such as the Eucalyptus (Myrtaceae) have more wood cavities and a wider range of hole sizes than small-trunk species (Gibbons \& Lindenmayer 1996, Lindenmayer et al. 2000). The larger the trunk diameter of Caryocar brasiliense (Caryocaraceae) trees, a typical species of the 'cerrado' region in Central Brazil, the more suitable hollows there will be for nesting by the eusocial bee Melipona quadrifasciata Lepeletier (Antonini \& Martins 2003).

The same trees that provide cavities for animals can also offer food products such as pollen, nectar, and potential preys (Fricke 1992, Manhart 1994), and useful materials for nest construction such as resins, gums, and oils (Fricke 1992, Gibbons \& Lindenmayer et al. 1996). Cavities can also house several other organisms that are food sources for several species of vertebrates and invertebrates.

Intrinsic and extrinsic factors affect cavity occupation and preference (Mccomb \& Noble 1982, Roubik 1989, Gibbons \& Lindenmayer 1996). Kind of cavity (dug or not in trunk or branch), animal size in relation to hollow entrance orifice size, cavity position on the tree, orientation, thermoregulatory capacity, and social organization of the animal species certainly influence cavity occupation and use.

The probability of invertebrates, including the Hymenoptera using tree cavities and hollows is positively correlated to the percentage of cortex in trunks, distance between the tree and the source of water or another tree with cavities, orifice entrance angle, and local density of trees (Mccomb \& Noble 1982). On the other hand, tree age, diameter and height, liana and epiphyte cover on the tree and cavity height relative to the ground are negatively correlated to the probability of cavity occupation and use (Mccomb \& Noble 1982).

Most animals occupying preexistent cavities probably 


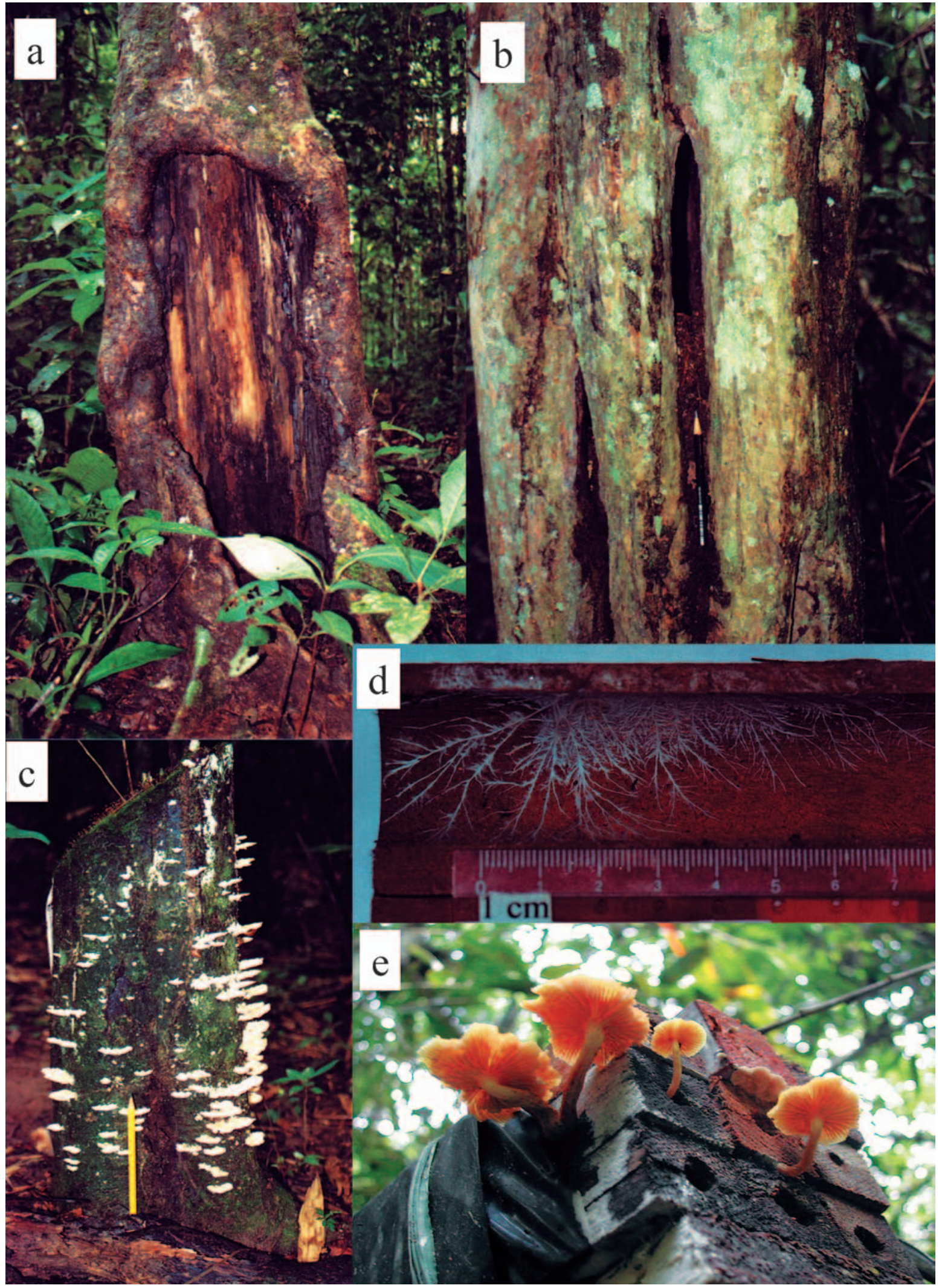

Fig. 1. Natural cavities in trunks of live (a,b) and dead trees (c) in a primary tropical forest near Rio Branco, Acre, Brazil and the growth of fungi inside (d) and outside (e) artificial cavities in wood. 
make their choices based upon tree species and physical quality of the hollows themselves (Gibbons \& Lindenmayer 1996). At least two evidences support these assumptions. First, the faunal species that occupy and use cavities in environments with distinct botanical compositions are similar. Second, most species are able to use artificial cavities that can be manufactured from timber of different plant species. Therefore, tree species does not seem to be the primary concern factor when choosing the nesting species. Nevertheless, information on solitary and social Aculeata nesting in preexisting wood cavities is not conclusive (Roubik 1989, Oliveira et al. 1995). The direct association between plant species and nesting activity has not been proved and the most determining factors when choosing the nesting site can be related to tree structural or architectural traits, and to timber physical or chemical properties (Hubbell \& Johnson 1977, Fowler 1979, Trugilho \& Vital 1996).

Fricke (1992) reported that nesting frequency of two crabonid Passaloecus Shuckard varied according to the tree species where the sampling trap-nests were attached. However, sampling in Fricke's study was insufficient for conclusions.

In a Central Amazonia, seasonally flooded forest, Garcia \& Adis (1993) studied the preference of the sphecid Penepodium goryanum (Lepeletier) females for trap-nests made from five very common tree species. The study was conducted in permanently and in seasonally flooded forests, where female nesting activity was not affected by the taxonomic identity of plant species.

A similar study was conducted on the nesting activity of the crabonid Trypoxylon rogenhoferi Kohl, in a seasonally flooded forest in Central Amazonia. In this case, trap-nests were made from the same timber botanical species as in the study by Garcia \& Adis (1993). Trap-nests made from two kinds of timber were more durable in the field and remained drier and free of fungi. Crabronid females did not prefer any of the taxonomic identities of species (Garcia \& Adis 1995).

Environmental changes that tend to reduce the

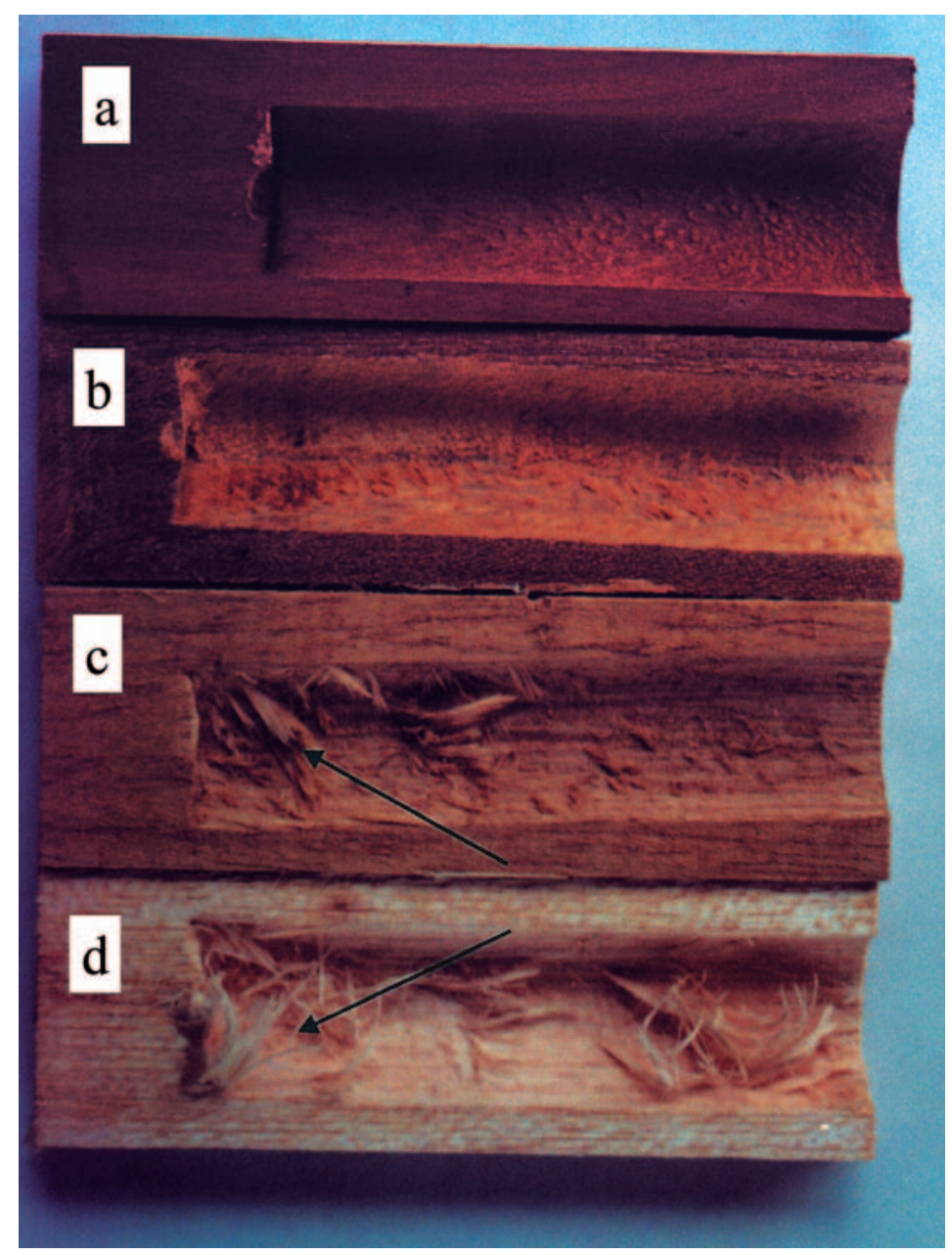

Fig. 2. Variation in physical and organoleptical properties among common species of tropical timbers in relation to wood fibrosity (pointing arrows): artificial cavities of M. amazonica (a); D. odorata (b); C. pentandra (c); and O. pyramidale (d). 


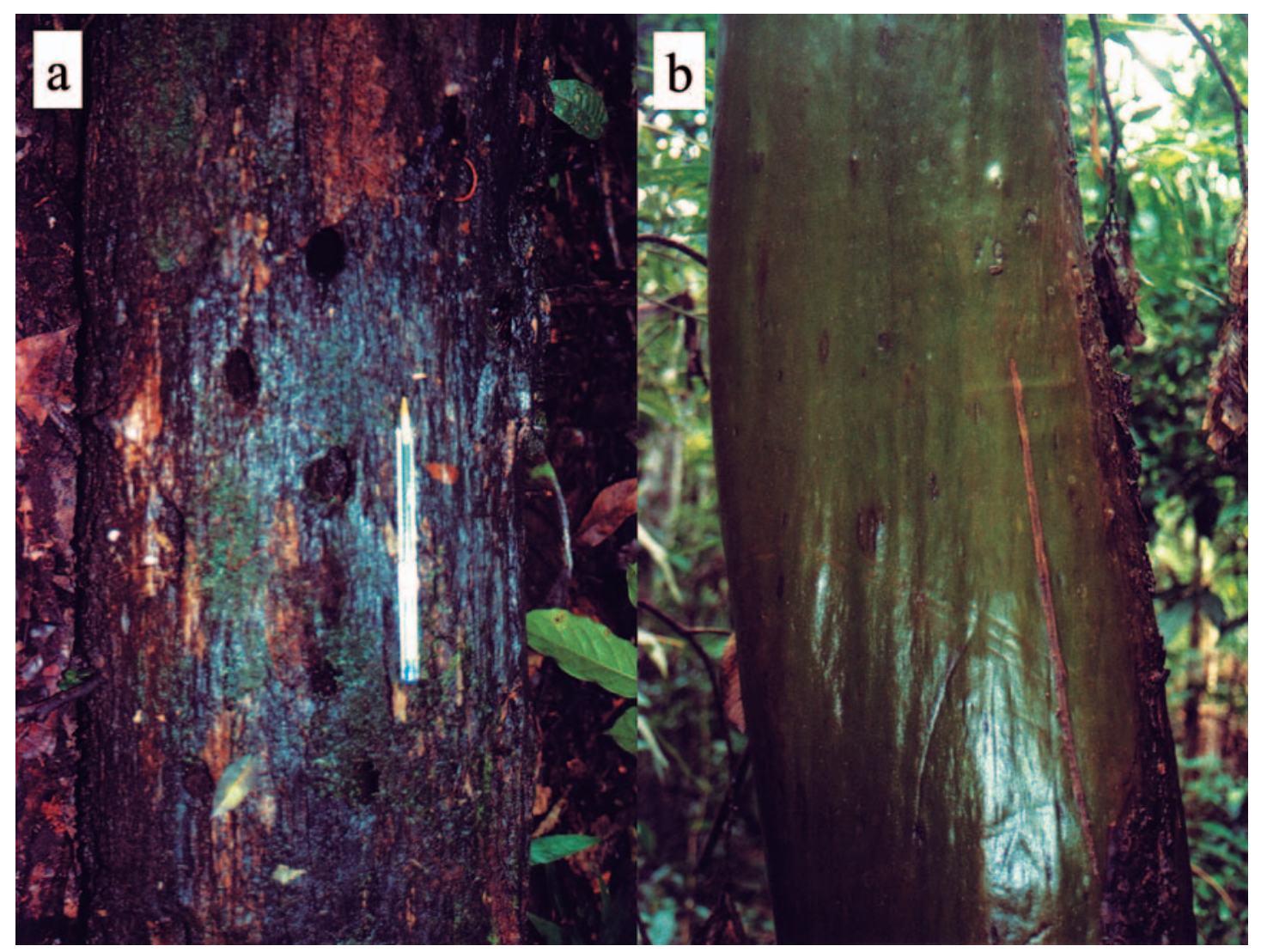

Fig. 3. Tropical forest trees and high proneness (a) and low proneness (b) to develop cavities.

availability of nesting sites for wasps and bees, such as deforestation, fragmentation, burnings, and monocultures can also decrease the species' population densities and consequently, their diversity of assemblages (Viana \& Melo 1987, Frankie et al. 1988, Vinson \& Frankie 1991, Vinson et al. 1993, Kerr et al. 1999, Morato \& Campos 2000a, Oliveira 2001) (Fig. 4).

Forest management for economic purposes can affect the availability of plant species and of natural cavities and hollows. Consequently, population densities of animals utilizing them can be affected (Pinard et al. 1999, Eltz et al. 2003) in two ways: by the mortality caused by the fall of trees during timber exploration (selective or not), and indirectly, by the lower availability of cavities.

Forest management for economic purposes has reduced population densities of temperate species of birds and marsupials (Newton 1994, Eltz et al. 2003). The scarcity of preexistent cavities seems to be more problematic under intensive forest management because very young trees are more frequently cut than in extensive management systems. In mature forests, the abundance and diversity of birds that nest in cavities tend to increase as the forest ages (Newton 1994). Selective timber explorations decrease the density of larger trees in tropical forests, which are more prone to have trunk and twig cavities and hollows (Kerr et al. 1999, Pinard et al. 1999).
The occupation of tree cavities by the social stingless bees in forests under timber exploration was studied by Eltz et al. (2003). They found that 91\% of nests were constructed in live trees and intact wood; nest housing trees were usually large $(\mathrm{dbh}>60 \mathrm{~cm})$; most tree species utilized by bees had commercial value; between $34 \%$ and $42 \%$ of them are potentially exploring species according to the management strategies predicted by specific legislation. Consequently, forest management that aims preserving the large trees enhances the populations of stingless bees and the flowering plants that rely on their pollination services. In a 'caatinga' region in Northeastern Brazil, more than $75 \%$ of stingless bee nests were found in only two tree species with local economic value for construction and firewood (Martins et al. 2004).

\section{Nesting by Solitary Aculeata in Preexisting Cavities in Wood}

Females of most species of solitary wasps burrow one or more nests in the soil (Evans 1966, Evans 1970, Evans \& Eberhard 1970, Rau \& Rau 1970, O’Neill 2001). Other species construct nests attached to vegetation or other substrates, utilizing mud and several plant materials (Evans \& Eberhard 1970, Dejean et al. 1998, O’Neill 2001).

In wasp and bee populations, there is a considerable amount of individual variation in relation to nest 
construction. For example, Trypoxylon politum Say females usually construct long, tubular, mud nests but can also nest in tree holes (Brockmann 1980). Many species are philopatric, i.e., the females of different and successive generations nest continuously in the same area where they emerged (Evans 1966, Rau \& Rau 1970, Antonini et al. 2000).

Nests of solitary wasps are provisioned with immature and adult spiders or insects belonging to other orders (Krombein 1967, Malyshev 1968, Evans \& Eberhard 1970, Bohart \& Menke 1976). All Masaridae species provision their nests with pollen and floral nectar (Evans \& Eberhard 1970, O'Neill 2001). Many species make their nests by removing pith from the stems and twigs of living and dead plants, or in preexisting cavities in the wood (Krombein 1960a, b; Evans 1966) (Fig. 5a). Females that nest in stems burrow inside to adapt their depth and diameter for the construction and provisioning of cells (Krombein 1960b, Evans \& Eberhard 1970, Rau \& Rau 1970, O’Neill 2001). Some wood physical characteristics seem to be preferred. For instance, some females burrow in decomposing tree trunks (Evans 1966, McIntosh 1996).

Species that use preexisting holes and cavities in wood, lack the burrowing behavior. First, the nesting females remove small chips, wood fragments, and other kinds of materials found blocking the cavity. The cell walls and partitions are constructed with materials as mud, sand grains, plant resins, small pieces of leaves, petals and grass filaments, fibers, small twigs, threads of spider webs, the female salivary secretions, and even small fragments of insect bodies (Fye 1965a; Medler 1965; Krombein 1967, 1970; Evans \& Eberhard 1970; O'Neill 2001). These cavities can be found in trunks and twigs of live and dead trees, and in the timber used for human constructions. This kind of nesting behavior is more frequently found among the solitary wasp species Crabronidae, Sphecidae, Pompilidae, and Vespidae (Eumeninae) (Evans \& Eberhard 1970, Bohart \& Menke 1976, O’Neill 2001).

The maintenance of predatory, solitary wasp populations depends on the availability of adequate sites for nesting and preying. Therefore, variations in the abundance and quality of sites can result in changes in the wasp population density and in the diversity of their assemblages (Janvier 1956, Evans 1966).

Similarly to wasps, different species of solitary bees can have a variety of nesting habits. Their nests can be made on the surface or underneath tree trunks, bushes, litter, termite or ant nests, or even on abandoned nests of other wasp and bee species (Coville et al.1983, Campos et al. 1987, Roubik 1989, Martins \& Almeida 1994, Almeida et al. 1997, Camargo \& Pedro 2003). Many species excavate their nests in exposed soil and can form large aggregations (Malyshev 1935, Michener 1974, Batra 1984, Roubik 1989, Martins \& Antonini 1994). Philopatry can occur among the digger species under stable environmental conditions (Michener 1974, Yanega 1990, Antonini et al. 2000, Michener 2000). Bee nests can be provisioned with pollen, nectar, and oils collected from flowers (Roubik 1989, Aguiar et al. 2003).

Females of many solitary bee species nest in sites other than those where mating took place and all adults forage for food and nesting materials (Janzen 1981, Westrich 1996). Knowing and preserving the solitary bee habitats are important for the maintenance of these Aculeata populations.

Other bee species nest in offside the twigs and branches, or in preexisting wood cavities and holes (Fye 1965b, Krombein 1967, Danks 1970, Frankie et al. 1988, Roubik 1989, Michener 2000, Silveira 2002) (Fig. 5b). Females that nest in twigs burrow inside to construct their cells (Michener 1974, Camillo et al. 1994, Michener 2000). Other species can burrow galleries in the hard wood of tree trunks (Linsley 1958).

Species that use preexisting holes and cavities in wood, can add several materials to their nests, such as sand grains, plant resins and oils, small pieces of leaves and petals, and sawdust (Krombein 1967). Cavities can be situated in trunks, twigs or branches of live or dead trees, and also in buildings (Linsley 1958). Some females can reuse the abandoned nests located in wood cavities (Linsley 1958, Vinson \& Frankie 2000, Silveira 2002), a common behavior among the species of Apidae, Megachilidae, and Colletidae (Krombein 1967, Roubik 1989, Michener 2000).

Wasp and bee species can be classified into guilds, according to their offspring and adult food sources and nesting substrates. A guild is a group of species that explore the same resource in a similar way (Price 1984). A guild usually contains species that are not related taxonomically, but explore a resource arbitrarily defined by a researcher (Jaksiæ 1981). When a resource is not a food source (e.g. a microhabitat) species can belong to different trophic levels (Jaksiæ 1981).

Solitary wasps and bees that use preexisting cavities for nest construction belong to one nesting guild. The Aculeata species that burrow their nests in the ground belong to a different nesting guild. The biology of the Aculeata species that nest in the soil is better known than for the biology of species that nest in other substrates, mostly because nests in the soil are more easily found. Aculeata site selection and nesting success seem to depend on soil topography and groundcover vegetation, besides several edaphic and microclimatic characteristics (Malyshev 1935, Michener et al. 1958, Evans 1966, Iwata 1976, Brockmann 1979, Cane 1991, Wesserling \& Tscharntke 1995, Potts \& Willmer 1997, Wuellner 1999, Ghazoul 2001).

Bees that nest in the soil are considered the most primitive group (Eickwort et al. 1981, Coville et al. 1983, Michener 2000). Above ground nesting behavior raised in Apidae, Megachilidae, Hylaeinae and Xylocopinae (Cane 1991). However, nesting behaviors vary widely among families. Females of several Crabronidae and Sphecidae species nest in preexisting wood cavities or in plant twigs and branches, as an evolutionary derived condition. In other cases, the opposite seems to occur (Evans 1966).

Natural selection favors wasp and bee traits associated with their nesting behaviors. Ghazoul (2001) showed that reproductive success among the solitary wasp Mellinus arvensis (L.) (Crabronidae) is a function of female size and soil physical properties. In sites with harder soils, females are more aggressive toward their conspecifics. In 


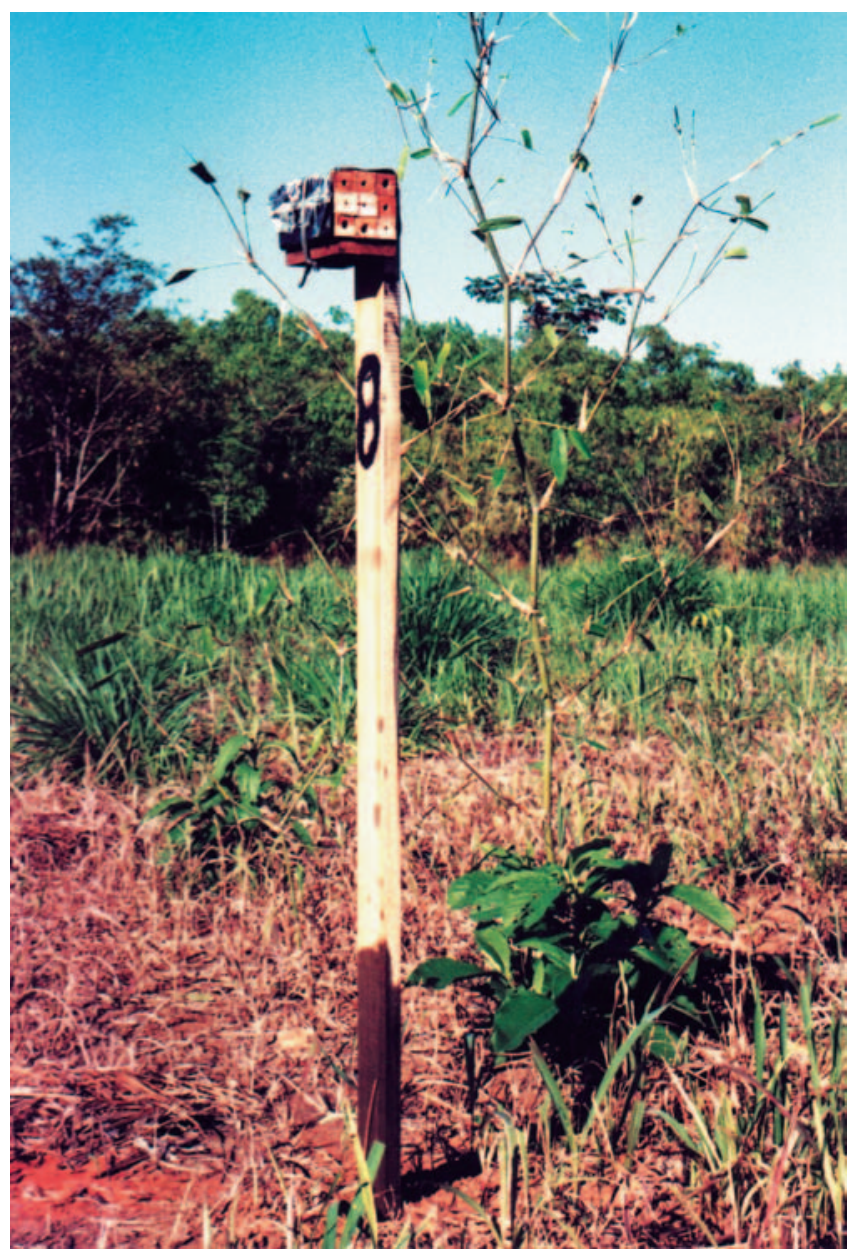

Fig. 4. Environmental disturbances can reduce the availability of natural cavities for nesting of solitary species of wasps and bees. Artificial cavities in the wood (trap-nests) have been used to monitor nesting activities of species in experimentally disturbed plots in western Amazonia, Acre, Brazil.

general, larger females are more successful in the usurpation of ready or beginning cavities. Soil hardness represents a selective pressure for female with larger bodies, which can enhance fitness of bigger females during agonistic encounters.

Females of Hylaeus grossus (Cresson) (Hymenoptera: Colletidae) construct their nests inside the hollows of dry twigs and branches (Michener \& Brooks 2003). Unlike the other species of Hylaeus, whose females build several brood cells grouped into a single cavity, the nests of this species contain only one or few brood cells, a condition considered apomorphic. Females often leave an exceptionally large empty space useless, in the cavity. Considering that branch cavities are not a limited resource where females nest, underutilizing the space has been interpreted as a risk-spreading strategy (Michener \& Brooks 2003).

Larger females of Trypoxylon rogenhoferi Kohl, a crabronid wasp species that nests in preexisting wood cavities, build more cells per day than smaller ones (Peruquetti \& Del Lama 2003b). During provisioning, larger females also prey a larger number of heavier spiders, and their adult offspring are also bigger. Therefore, female body size of $T$. rogenhofer $i$ increases the chances for reproductive success.

The Aculeata nests located in preexisting cavities usually have a linear series of cells separated by partitions (Krombein 1967). In some species, cell partitions can be absent (Evans \& Eberhard 1970). The number of cells in the nest varies among and within species. In nests of some species one can find empty spaces at the end or in the middle of the linear series of provisioned cells, called vestibular and intercalary cells, respectively. The empty spaces prevent the egg and the immature from predation or parasitism by natural enemies (Krombein 1967).

Nests are rarer among species that build their nests in preexisting wood cavities than among species that dig the soil (Danks 1971a, b; Jayasingh \& Freeman 1980; LaSalle \& Gauld 1993; Edwards 1996). Several factors determine nesting success of the solitary Aculeata species in preexisting cavities: availability of suitable cavities (Vinson et al. 1993, Edwards 1996), female size (Fricke 1991a, b; Kim 1997; Peruquetti \& Del Lama 2003b), distance between nesting site and food source for adults and their offspring (Roubik 1989, Manhart 1994, Horne 1995a, Westrich 1996), and availability of nest-building materials (Roubik 1989, Horne 1995b, Westrich 1996, Alves-dos-Santos et al. 2002). The availability of materials utilized in nest construction is limited in nesting sites. According to Vinson et al. (1993), the cavities in wood, sawdust, and small chips of wood used by females of some species of Centris Fabricius are not readily available as spots of aggregated particles in the environment, due to air currents. These species of Centris Fabricius are unable to dig in the wood and rely mostly on boring wood insects to build the nests (Borror et al. 1992). The activities of wood boring insects are highly dependent on quality wood, which can be the main reason for the Aculeate species to nest primarily in preexisting holes in human-made environments (Krombein 1967), where cavities are not due to the action of boring insects.

The great amount of leaf fragments found in bee nests of the genus Megachile Latreille suggests that females bring them from nearby areas (Michener 1953). The physical structure and chemical composition of the leaf fragments are of fundamental importance for female nesting success (Horne 1995a, b). Saponines present in the leaves of some plant species cause larval mortality in Megachile rotundata (Fabricius). Leaves differ in toughness, and nesting females may need to press their mandibles strongly, to properly cut the leaves to be used for cell construction. Therefore, not all leaves in the environment are structurally or chemically suitable for cell construction by megachilid bees and can not guarantee nesting success.

It is well known that wood cavity size influences the number of cells constructed by females and that cell size affects sex ratio (Rau 1932; Krombein 1967; Coville 1982; Tepedino \& Torchio 1989; Camillo et al. 1996, 1997; Kim 1997; O’Neill 2001; Peruquetti \& Del Lama 2003b), the body size (Krombein 1967, Evans \& Eberhard 1970, Tepedino \& Torchio 1989, 


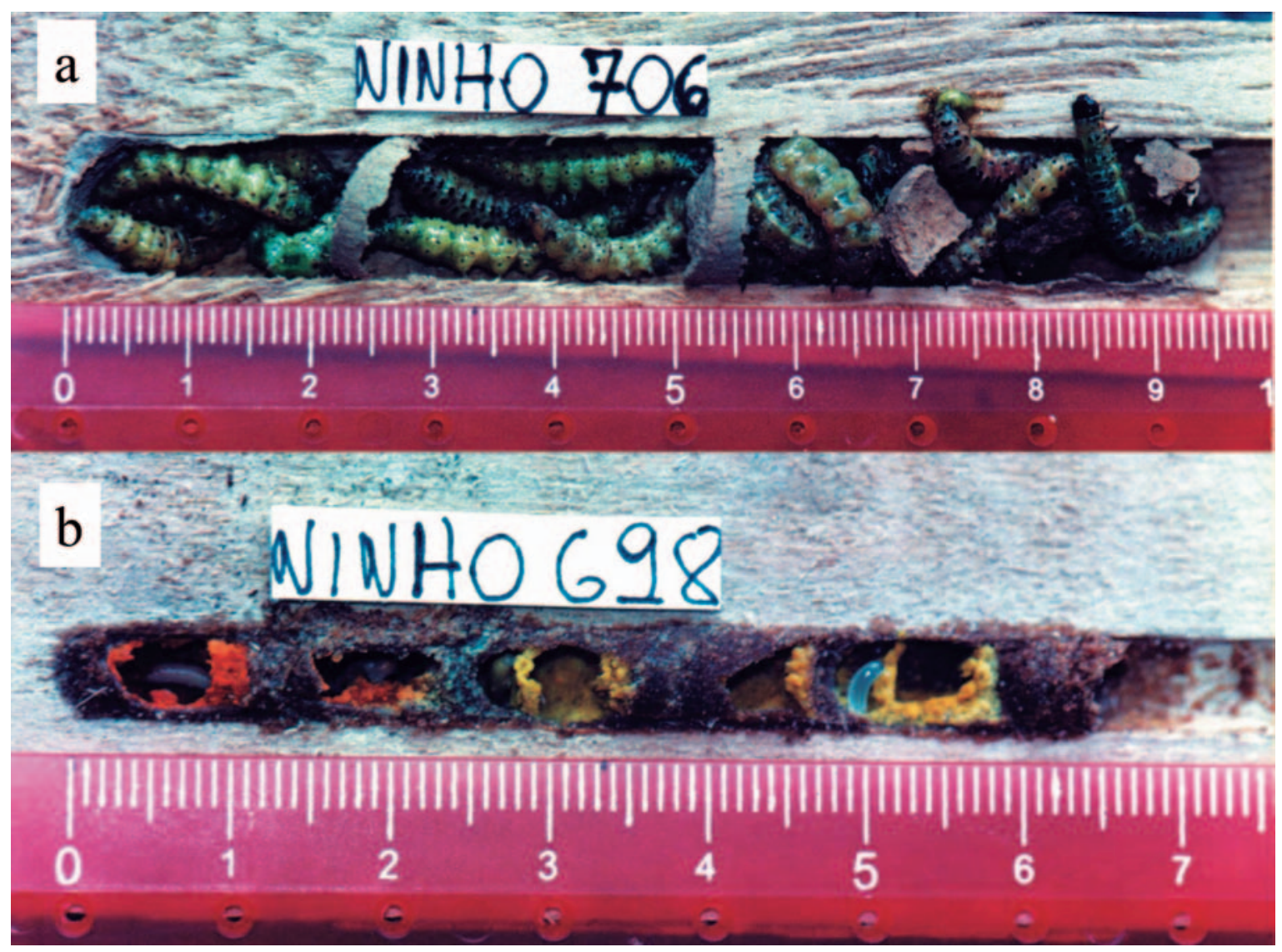

Fig. 5. Provisioned nests of the wasp M. angulosa, a predator of caterpillars (a) and the bee Tetrapedia sp. (Apidae).

Roulston \& Cane 2000, Peruquetti \& Del Lama 2003b) and the fitness of the progeny (Alcock 1979, Roulston \& Cane 2000, Peruquetti \& Del Lama 2003b).

Nest usurpation is very common among solitary wasp and bee species (Krombein 1967, Eickwort 1975, Coville 1982, Alexander 1986, Matthews 1991, McCorquodale \& Owen 1994, Kim 1997, Michener 2000, Vinson \& Frankie 2000, O’Neill 2001). Empirical (Cooper 1953, Bohart 1955, Medler \& Koerber 1957, Danks 1970, Eickwort 1975, Coville \& Coville 1980, Coville 1982, Strickler et al. 1996, Frankie et al. 1998) and experimental (Thorp et al. 1992, Barthell et al. 1998, Vinson \& Frankie 2000) findings show that competition for nesting sites is important to determine the reproductive success of many species. Evidence on the prey stealing behavior has also been reported for some species of solitary predator wasps (Alexander 1986, Matthews 1991).

Tepedino \& Torchio (1994) offered wood trap-nests placed in greenhouse to the bee Osmia lignaria Say (Megachilidae). Although trap-nests were offered in excess, approximately $75 \%$ of the nesting females usurped at least one nest, and $65 \%$ of them lost at least one nest for another female. Approximately $50 \%$ of the females usurped nests and also had their own nests usurped. About $25 \%$ of all constructed nests were usurped. Both usurper and usurped females tended to select cavities in the same place and with the same diameter as cavities previously utilized for their nest construction.

Nesting behavior and mating sites vary widely among the solitary Aculeate species (Evans \& Eberhard 1970, Spradbery 1973, Eickwort \& Ginsberg 1980, Thornhill \& Alcock 1983, Roubik 1989, Cure \& Wittmann 1990, Gaglianone 2000, Morato \& Campos 2000b, O’Neill 2001, Medeiros \& Schlindwein 2003). Most species of the crabonid wasp Trypoxylon Latreille sub-genus Trypargilum Richards (sensu Richards 1934) mate near or inside their own nests, located in preexisting cavities in wood. The males guard the nest against intruders and assist nesting females in storing preys in the nests (Krombein 1967, Paetzel 1973, Coville \& Coville 1980, see revision in Coville 1982).

Males of the crabonid wasp species Trypoxylon Latreille search actively for empty cavities or follow the conspecific nesting females to a cavity; once they reach the cavity, they remain in guard inside. Females search for nesting materials and prey upon spiders whereas males defend the nest against usurpation by other conspecific nesting female wasps (Richards 1934, Krombein 1967) or males (Coville \& Coville 1980, Coville 1981, Brockmann \& Grafen 1989, Brockmann 1992), or against parasites and predators. Shortly after females return to their nests, they copulate several times just before egg laying. A female lays an egg 
only when the cell contains enough preys. In some cases, males guard the nests until the larvae have spun the cocoons. Nesting guard males can also aid females to construct and clean the nest, and place and arrange the spiders collected in the cells (Krombein 1967, Paetzel 1973, Coville \& Coville 1980, see Coville 1982 for a review).

Male parental care is not common among other Aculeata species (Hamilton 1972, Coville \& Coville 1980) and can be considered an important evolutionary trait in increasing male and female fitness, thus guaranteeing male paternity. Due to haplodiploidy, the nest guarding behavior and the copulations in the nest can indirectly increment female production, sex being genetically related to the male. This is possible when females allocate more time and become more efficient in foraging while the males protect their nests.

On the other hand, females of the crabronid wasp species Trypoxylon Latreille exert a strong sexual selection pressure on males, usually mating only with nest-guarding males (Thornhill \& Alcock 1983). Therefore, the reproductive success of this wasp species depends not only on cavity and food availability, but also on the existence of nest-guarding males. Brockmann \& Grafen (1989) were concerned about male efficiency in defending small and large cavities. When male progeny is not genetically related to the father, fewer males will be found in nests built in small cavities. Males are produced mostly in small cells provisioned with a small amount of food (O’Neill 2001). The prey biomass stocked in cells of nests constructed in small cavities is lower than prey biomass provisioned in larger cavities. Ovules (n) will preferably be placed in cells with small amount of food, thus increasing the chances for raising male individuals, as opposed to eggs (2n), which would raise female individuals. Therefore, the hypothesis that females have a smaller chance to find conspecific guarding males in small cavities needs to be tested.

Male nest-guarding behavior among the sub-genus Trypoxylon has not been reported yet (Bohart \& Menke 1976, Coville 1982, Peruquetti \& Del Lama 2003a). Nest construction and cell provisioning behaviors among species of the sub-genus Trypoxylon need to be studied. It is necessary to investigate also if the predation, parasitism and nest usurpation pressure is stronger on species of this group than on Trypargilum ones.

\section{Use of Cavities in Wood by Other Animals}

Several vertebrate and invertebrate animal species other than the Aculeata insects use preexisting holes and cavities in wood for nesting and other activities (Koerber \& Medler 1958, Krombein 1967, Mccomb \& Noble 1982, Thorp et al. 1992, Martin \& Eadie 1999, Eltz et al. 2003, Bate et al. 2004, Warren et al. 2005). Approximately 400 species of Australian vertebrates use cavities in wood (Gibbons \& Lindenmayer 1996). According to Mccomb \& Noble (1982), and $48 \%$ of the natural and artificial cavities in temperate forests are occupied by invertebrates, mainly Orthoptera (20\%) and Hymenoptera (10\%). A 23-month monitoring has showed that occupation of artificial cavities is strongly correlated with occupation of natural cavities.
The exploration of microhabitats in decomposing trees and trunks is an evolutionary behavior for several groups of insects and a primitive stage for others (Hamilton 1978). Cavities in live trees are preferred for nesting than those in dead trees; this can be partially explained by the microclimate inside cavities (Mccomb \& Noble 1982, Nicolai 1986, Parker 1986, Tepedino \& Parker 1986). The maintenance of a suitable microclimate is important for the development of Aculeate offspring nesting in wood cavities (Frankie et al. 1988).

Only the eusocial wasps (Spradbery 1973) and bees (Michener 1974, Roubik 1989) are able to exert thermoregulation in their nests. Solitary aculeates prefer to nest in suitable cavities, with more or less insulation (Parker 1986, Frankie et al. 1988), or with resistance to climatic variations in the external environment (Michener 1974).

Live trees control and buffer thermal variations in cavities more efficiently (Gibbons \& Lindenmayer 1996). For some animal species, cavities in dead trees or rotten logs are not suitable for nesting. Furthermore, termites that nest in, or that attack physiologically weak or dead trees produce a great amount of colloidal substances that are a heat source for the fauna using cavities (Gibbons \& Lindenmayer 1996).

\section{Conclusions}

The management of native and cultivated forests and other kinds of vegetation may contribute remarkably for the conservation of the wild fauna that reproduces in natural cavities and hollows in wood. Further studies on the subject are still needed and, among them, research on whether conservation strategies and retention of trees that offer cavities for animal species that require large holes are also effective for species that need small cavities.

The solitary aculeate insects are more prone to construct nests in dead trees and in poor quality and low durability timber than eusocial insects because the former have shorter life cycles and make nests in relatively smaller cavities (Michener 1974, Roubik 1989). However, intense deforestation and timber exploration can have similar impacts on populations of both groups. These impacts could be worse on the solitary species due to their lower fertility and for their rarity (Danks 1971a, b; Jayasingh \& Freeman 1980; LaSalle \& Gauld 1993; Edwards 1996; Peruquetti \& Del Lama 2003).

Most studies on this theme focus on the vertebrate species. However, invertebrates as the solitary wasps and bees ought to be of more concern, due to their key roles and ecological services in the terrestrial ecosystems.

\section{Acknowledgements}

Authors are indebted to Moises Silveira Lobão and Francesca Salla (Xyloteca, Universidade Federal do Acre, Brazil), who provided wood trap-nests and enriching discussions about tropical timbers. Thanks are due to CAPES, for the doctoral fellowship to the first outhor (PICDT0002/99-2) and to CNPq, for the research scholarship to the second author. This study is a contribution 
of the Graduate Program of Ecology and Wildlife Management of the Universitdade Federal de Minas Gerais, Belo Horizonte, MG, Brazil.

\section{References}

Abreu, R.L.S., C. Salles-Campos, R.E. Hanada, F.J. Vasconcelos \& J.A. Freitas. 2002. Avaliação de danos por insetos em toras estocadas em indústrias madeireiras de Manaus, Amazonas, Brasil. R. Árvore 26: 789-796.

Aguiar, C.M.L., F.C.V. Zanella, C.F. Martins \& C.A.L. de Carvalho. 2003. Plantas visitadas por Centris spp. (Hymenoptera: Apidae) na Caatinga para obtenção de recursos florais. Neotrop. Entomol. 32: 247-259.

Alcock, J. 1979. The relation between female body size and provisioning behavior in the bee Centris pallida Fox (Hymenoptera: Anthophoridae). J. Kansas Entomol. Soc. 52: 623-632.

Alexander, B. 1986. Alternative methods of nest provisioning in the digger wasp Clypeadon laticinctus (Hymenoptera: Sphecidae). J. Kansas Entomol. Soc. 59: 59-63.

Almeida, D.A.O., R.P. Martins \& M.L.T. Buschini. 1997. Behavior and nesting dynamics of the neotropical cavity-nesting specialist bee Megachile assumptionis Schrottky, with comparisons to the neartic Megachile brevis Say (Hymenoptera: Megachilidae). J. Hymenopterol. Res. 6: 344352.

Alves-dos-Santos; I., G.A.R. Melo \& J.G. Rozen Jr. 2002. Biology and immature stages of the bee tribe Tetrapediini (Hymenoptera: Apidae). Amer. Mus. Novit. 3377: 1-45.

Antonini, Y., C.M. Jacobi \& R.P. Martins. 2000. Philopatry in the neotropical ground-nesting solitary digger bee, Diadasina distincta (Holmberg, 1903) (Hymenotpera: Apidae) at a nesting site in southeastern Brazil. Rev. Etol. 2: 111-119.

Antonini, Y. \& R.P. Martins. 2003. The value of a tree species (Caryocar brasiliense) for a stingless bee Melipona quadrifasciata quadrifasciata. J. Insect Conserv. 7: 167-174.

Apetorgbor, M.M., N.A. Darkwa, O. Frimpong \& V.K. Agyeman. 2004. Biodeteriorating agents associated with three tropical timber species. For. Ecol. Manage. 195: 311-323.

Barthell, J.F., G.W. Frankie \& R.W. Thorp. 1998. Invader effects in a community of cavity nesting megachilid bees (Hymenoptera: Megachilidae). Environ. Entomol. 27: 240-247.

Bate, L.J., T.R. Torgersen, M.J. Wisdom \& E.O. Garton. 2004. Performance of sampling methods to estimate $\log$ characteristics for wildlife. For. Ecol. Manage. 199: 83-102.

Batra, S.W. 1984. Solitary bees. Sci. Am. 250: 86-93.

Berryman, A.A. 1986. Forest insects: Principles and practice of population management. New York, Plenum Press, 279p.

Bohart, R.M. 1955. Gradual nest supersedure within the genus Osmia. Proc. Entomol. Soc. Wash. 57: 203-204.

Bohart, R.M. \& A.S. Menke. 1976. Sphecid wasps of the world: a generic revision. Berkeley, University of California Press, 695p.
Borror, D.J., C.A. Triplehorn \& N.F. Johnson. 1992. An introduction to the study of insects. 6 ed. Fort Worth, Saunders College Publishing, 875p.

Brockmann, H.J. 1979. Nest-site selection in the great golden digger wasp, Sphex ichneumoneus L. (Sphecidae). Ecol. Entomol. 4: 211-224.

Brockmann, H.J. 1980. Diversity in the nesting behavior of muddaubers (Trypoxylon politum Say; Sphecidae). Fla. Entomol. 63: 53-63.

Brockmann, H.J. 1992. Male behavior, courtship, and nesting in Trypoxylon (Trypargilum) monteverdae (Hymenoptera: Sphecidae). J. Kans. Entomol. Soc. 65: 66-84.

Brockmann, H.J. \& A. Grafen. 1989. Mate conflict and male behaviour in a solitary wasp, Trypoxylon (Trypargilum) politum (Hymenoptera: Sphecidae). Anim. Behav. 37: 232-255.

Burger, L.M. \& H.G. Richter. 1991. Anatomia da madeira. São Paulo, Ed. Nobel, 154p.

Camargo, J.M.F. \& S.R.M. Pedro. 2003. Meliponini neotropicais: o gênero Partamona Schwarz, 1939 (Hymenoptera, Apidae, Apinae) - bionomia e biogeografia. Rev. Bras. Entomol. 47: 311-372.

Camillo, E., C.A. Garófalo \& J.C. Serrano. 1994. Nesting activities and nest reuse of Lithurge huberi (Hymenoptera, Megachilidae). Rev. Bras. Biol. 54: 183-194.

Camillo, E., C.A. Garófalo \& J.C. Serrano. 1997. Biologia de Monobia angulosa Saussure em ninhos armadilhas (Hymenoptera: Vespidae: Eumeninae). An. Soc. Entomol. Bras. 26: 169- 175.

Camillo, E., C.A. Garófalo, J.M.F. de Assis \& J.C. Serrano. 1996. Biologia de Podium denticulatum Smith em ninhosarmadilhas (Hymenoptera: Sphecidae: Sphecinae). An. Soc. Entomol. Bras. 25: 439-450.

Campos, L.A.O., E. F. Morato, G.R. de Melo \& F.A. da Silveira. 1987. Abelhas - características e importância. Inf. Agropec. 13: 7-15.

Cane, J.H. 1991. Soils of ground-nesting bees (Hymenoptera: Apoidea): Texture, moisture, cell depth and climate. J. Kansas Entomol. Soc. 64: 406-413.

Cooper, K.W. 1953. Biology of eumenine wasps I. The ecology, predation, nesting and competition of Ancistroceroides antilope (Panzer). Trans. Am. Entomol. Soc. 79: 13-35.

Coville, R.E. 1981. Biological observations on three Trypoxylon wasps in the subgenus Trypargilum from Costa Rica: $T$. nitidum schulthessi, T. saussurei, and T. lactitarse (Hymenoptera: Sphecidae). Pan-Pac. Entomol. 57: 332-340.

Coville, R.E. 1982. Wasps of the genus Trypoxylon subgenus Trypargilum in North America (Hymenoptera: Sphecidae). Univ. Calif. Publ. Entomol. 97: 1-147.

Coville, R.E., G.W. Frankie \& S.B. Vinson. 1983. Nests of Centris segregata (Hymenoptera: Anthophoridae) with a review of the nesting habits of the genus. J. Kansas Entomol. Soc. 56: 109-122.

Coville, R.E. \& P.L. Coville. 1980. Nesting biology and male 
behavior of Trypoxylon (Trypargilum) tenoctitlan in Costa Rica (Hymenoptera: Sphecidae). Ann. Entomol. Soc. Am. 73: 110-119.

Cure, J.R. \& D. Wittmann. 1990. Callonychium petuniae, a new panurgine bee species (Apoidea, Andrenidae), oligolectic on Petunia (Solanaceae). Stud. Neotrop. Environ. 25: 153-156.

Daly, H.V., J.T. Doyen \& P.R. Ehrlich. 1978. Introduction to insect biology and diversity. New York, McGraw-Hill, 564p.

Danks, H.V. 1970. Biology of some stem-nesting aculeate Hymenoptera. Trans. R. Entomol. Soc. Lond. 122: 323-399.

Danks, H.V. 1971a. Populations and nesting-sites of some aculeate Hymenoptera nesting in Rubus. J. Anim. Ecol. 40: 63-77.

Danks, H.V. 1971b. Nest mortality factors in stem-nesting aculeate Hymenoptera. J. Anim. Ecol. 40: 79-82.

Dejean, A., B. Corbara \& J.M. Carpenter. 1998. Nesting site selection by wasps in the Guianese rain forest. Insectes Soc. 45: 33-41.

Dorval, A., O. Peres Filho \& E.N. Marques. 2004. Levantamento de Scolytidae (Coleoptera) em plantações de Eucalyptus spp. em Cuiabá, Estado de Mato Grosso. Ciência Florestal 14: 4758.

Edwards, M. 1996. Optimizing habitats for bees in the United Kingdom - a review of recent conservation action, p.35-45. In A. Matheson, S.L. Buchmann, C. O’toole, P. Westrich \& I.H. Williams (eds.), The conservation of bees. London, Academic Press, 254p.

Eickwort, G.C. 1975. Gregarious nesting of the mason bee Hoplitis anthocopoides and the evolution of parasitism and sociality among megachilid bees. Evolution 29: 142-150.

Eickwort, G.C. \& H.S. Ginsberg. 1980. Foraging and mating behavior in Apoidea. Annu. Rev. Entomol. 25: 421-446.

Eickwort, G.C., R.W. Matthews \& J. Carpenter. 1981. Observations on the nesting behavior of Megachile rubi and M. texana with a discussion of the significance of soil nesting in the evolution of megachilid bees (Hymenoptera: Megachilidae). J. Kansas Entomol. Soc. 54: 557-570.

Eltz, T., C.A. Brühl, Z. Imiyabir \& K.E. Linsenmair. 2003. Nesting and nest trees of stingless bees (Apidae: Meliponini) in lowland dipterocarp forests in Sabah, Malaysia, with implications for forest management. For. Ecol. Manage. 172: 301-313.

Engelmann, F. 1970. The physiology of insect reproduction. Oxford, Pergamon Press, 307p.

Evans, H.E. 1966. The behavior patterns of solitary wasps. Annu. Rev. Entomol. 11: 123-154.

Evans, H.E. 1970. Ecological-behavioral studies of the wasps of Jackson Hole, Wyoming. Bull. Mus. Comp. Zool. 140: 451511.

Evans, H.E. \& M.J.W. Eberhard. 1970. The wasps. Ann Arbor, The University of Michigan Press, 265p.

Forest Products Laboratory. 1974. Wood handbook: Wood as engineering material. Washington, U.S. Department of
Agriculture, 521p.

Fowler, H.G. 1979. Responses by a stingless bee to a subtropical environment. Rev. Biol. Trop. 27: 111-118.

Frankie, G.W., R.W. Thorp, L.E. Newstrom-Lloyd, M.A. Rizzardi, J.F. Barthell, T.L. Griswold, J.-Y. Kim \& S. Kappagoda. 1998. Monitoring solitary bees in modified wildland habitats: Implications for bee ecology and conservation. Environ. Entomol. 27: 1137-1148.

Frankie, G.W., S.B. Vinson, L.E. Newstrom \& J.F. Barthell. 1988. Nest site and habitat preferences of Centris bees in the Costa Rican dry forest. Biotropica 20: 301-310.

Fricke, J.M. 1991a. Trap-nest design for small trap-nesting Hymenoptera. Gt. Lakes Entomol. 24: 121-122.

Fricke, J.M. 1991b. Trap-nest bore diameter preferences among sympatric Passaloecus spp. (Hymenoptera: Sphecidae). Gt. Lakes Entomol. 24: 123-125.

Fricke, J.M. 1992. Influence of tree species on frequency of trapnest use by Passaloecus species (Hymenoptera: Sphecidae). Gt. Lakes Entomol. 25: 51-53.

Fye, R.E. 1965a. The biology of Vespidae, Pompilidae, and Sphecidae (Hymenoptera) from trap nests in Northwestern Ontario. Can. Entomol. 97: 716-744.

Fye, R.E. 1965b. Biology of Apoidea taken in trap nests in Northwestern Ontario (Hymenoptera). Can. Entomol. 97: 863877.

Gaglianone, M.C. 2000. Behavior on flowers, structures involved in pollen transport and nesting biology of Perditomorpha brunerii and Cephalurgus anomalus (Hymenoptera: Colletidae, Andrenidae). Rev. Biol. Trop. 48: 89-99.

Ganey, J.L. \& S.C. Vojta. 2004. Characteristics of snags containing excavated cavities in northern Arizona mixed-conifer and ponderosa pine forests. For. Ecol. Manage. 199: 323-332.

Garcia, M.V.B. \& J. Adis. 1993. On the biology of Penepodium goryanum (Lepeletier) in wooden trap-nests (Hymenoptera, Sphecidae). Proc. Entomol. Soc. Wash. 95: 547-553.

Garcia, M.V.B. \& J. Adis. 1995. Comportamento de nidificação de Trypoxylon (Trypargilum) rogenhoferi KOHL (Hymenoptera, Sphecidae) em uma floresta inundável de várzea na Amazônia Central. Amazoniana 13: 259-282.

Ghazoul, J. 2001. Effect of soil hardness on aggression in the solitary wasp Mellinus arvensis. Ecol. Entomol. 26: 457-466.

Gibbons, P. \& D.B. Lindenmayer. 1996. Issues associated with the retention of hollow-bearing trees within eucalypt forests managed for wood production. For. Ecol. Manage. 83: 245-279.

Hamilton, W.D. 1972. Altruism and related phenomena, mainly in social insects. Annu. Rev. of Ecol. Syst. 3: 193-232.

Hamilton, W.D. 1978. Evolution under bark, p.154-175. In L.A. Mound \& N. Waloff (eds.), Diversity of insect faunas. Oxford, Blackwell Scientific Publications, 294p.

Hill, D.S. 1997. The economic importance of insects. London, Chapman \& Hall, 395p. 
Horne, M. 1995a. Pollen preference and its relationship to nesting success of Megachile rotundata (Hymenoptera: Megachile). Ann. Entomol. Soc. Am. 88: 862-867.

Horne, M. 1995b. Leaf area and toughness: effects on nesting material preferences of Megachile rotundata (Hymenoptera: Megachile). Ann. Entomol. Soc. Am. 88: 868-875.

Hubbell, S.P. \& L.K. Johnson. 1977. Competition and nest spacing in a tropical stingless bee community. Ecology 58: 949-963.

Iwata, K. 1976. Evolution of instinct: comparative ethology of Hymenoptera. Washington, D.C., Smithsonian Institution and National Science Foundation, 535p.

Jaksiæ, F.M. 1981. Abuse and misuse of the term "guild" in ecological studies. Oikos 37: 397-400.

Janvier, H. 1956. Hymenopterous predators as biological control agents. J. Econ. Entomol. 49: 202-205.

Janzen, D.H. 1981. Bee arrival at two Costa Rican female Catasetum orchid inflorescences, and a hypothesis on euglossine population. Oikos 36: 177-183.

Jayasingh, D.B. \& B.E. Freeman. 1980. The comparative population dynamics of eight solitary bees and wasps (Aculeata; Apocrita; Hymenopera) trap-nested in Jamaica. Biotropica 12: 214-219.

Jesus, M.A., J.W. Morais, R.L.S. Abreu \& M. de F.C. Cardias. 1998. Durabilidade natural de 46 espécies de madeira amazônica em contato com o solo em ambiente florestal. Sc. Forest. 54: 81-92.

Kerr, W.E., G.A. Carvalho \& V.A. Nascimento. 1999. The probable consequences of the destruction of Brazilian stingless bees, p.395-403. In C. Padoch, J.M. Ayres, M. Pinedo-Vasquez \& A. Henderson (eds.), Várzea: Diversity, development, and conservation of Amazonia's whitewater floodplains. New York, The New York Botanical Garden Press, 407p.

Kim, J.-Y. 1997. Female size and fitness in the leaf-cutter bee Megachile apicalis. Ecol. Entomol. 22: 275-282.

Koerber, T.W. \& J.T. Medler. 1958. A trap-nest survey of solitary bees and wasps in Wisconsin, with biological notes. Trans. Wis. Acad. Sc. Arts Lett. 47: 53-63.

Krombein, K.V. 1960a. Biological notes on some Hymenoptera that nest in sumach pith. Entomol. News 71: 29-36.

Krombein, K.V. 1960b. Biological notes on some Hymenoptera that nest in sumach pith. Entomol. News 71: 63-69.

Krombein, K.V. 1967. Trap-nesting wasps and bees: life histories, nests and associates. Washington, Smithsonian Press, 569p.

Krombein, K.V. 1970. Behavioral and life history notes on three Floridian solitary wasps (Hymenoptera: Sphecidae). Smithson. Contrib. Zool. 46: 26p.

LaSalle, J. \& I.D. Gauld. 1993. Hymenoptera: their diversity, and their impact on the diversity of other organisms, p.1-26. In J. LaSalle \& I.D. Gauld (eds.), Hymenoptera and biodiversity. Wallingford, C.A.B. International, 348p.

Lindenmayer, D.B., R.B. Cunningham, H.A. Nix, M.T. Tanton \&
A.P. Smith. 1991. Predicting the abundance of hollow-bearing trees in montane forests of southeastern Australia. Aust. J. Ecol. 16: 91-98.

Lindenmayer, D.B., R.B. Cunningham, M.L. Pope, P. Gibbons \& C.F. Donnelly. 2000. Cavity sizes and types in Australian eucalypts from wet and dry forest types - a simple of rule of thumb for estimating size and number of cavities. For. Ecol. Manage. 137: 139-150.

Linsley, E.G. 1958. The ecology of solitary bees. Hilgardia 27: 543-599.

Malyshev, S.I. 1935. The nesting habits of solitary bees: A comparative study. EOS 11: 201-309.

Malyshev, S.I. 1968. Genesis of the Hymenoptera and the phases of their evolution. London, Methuen and Co., 319p.

Manhart, C. 1994. Spiders on bark in a tropical rainforest (Panguana, Peru). Stud. Neotrop. Environ. 29: 49-53.

Martin, K. \& J.M. Eadie. 1999. Nest webs: a community-wide approach to the management and conservation of cavitynesting forest birds. For. Ecol. Manage. 115: 243-257.

Martins, C.F., M. Cortopassi-Laurino, D. Koedam \& V.L. Imperatriz-Fonseca. 2004. Tree species used for nidification by stingless bees in the brazilian caatinga (Seridó, PB; João Câmara, RN). Biota Neotropica 4: 1-8.

Martins, R.P. \& D.A.O. de Almeida. 1994. Is the bee Megachile assumptionis a cavity-nesting specialist? J. Insect Behav. 7: 759-765.

Martins, R.P. \& Y. Antonini. 1994. The biology of Diadasina distincta (Holmberg, 1903) (Hymenoptera: Anthophoridae). Proc. Entomol. Soc. Wash. 96: 553-560.

Matthews, R.W. 1991. Evolution of social behavior in sphecid wasps, p. 570-602. In K.E. Ross \& R.W. Matthews (eds.), The social biology of wasps. Ithaca, Comstock Publishing Associates, 678p.

Mccomb, W.C. \& R.E. Noble. 1982. Invertebrate use of natural tree cavities and vertebrate nest boxes. Am. Midl. Nat. 107: 163-172.

McCorquodale, D.B. \& R.E. Owen. 1994. Laying sequence, diploid males, and nest usurpation in the leafcutter bee, Megachile rotundata (Hymenoptera: Megachilidae). J. Insect Behav. 7: 731-738.

McIntosh, M. 1996. Nest-substrate preferences of the twig-nesters Ceratina acantha, Ceratina nanula (Apidae) and Pemphredon lethifer (Sphecidae). J. Kansas Entomol. Soc. 69: 216-231.

Medeiros, P.C.R. \& C. Schlindwein. 2003. Territórios de machos, acasalamento, distribuição e relação com plantas em Protomeliturga turnerae (Ducke, 1907) (Hymenoptera, Andrenidae). Rev. Bras. Entomol. 47: 589-596.

Medler, J.T. 1965. Biology of Isodontia (Murrayella) mexicana in trap-nests in Wisconsin (Hymenoptera: Sphecidae). Ann. Entomol. Soc. Am. 58: 137-142.

Medler, J.T. \& T.W. Koerber. 1957. Biology of Dipogon sayi Banks in trap-nests in Wisconsin. Ann. Entomol. Soc. Am. 50: 621-625. 
Metcalf, C.R. \& L. Chalk. 1983. Anatomy of the dicotyledons. II. wood structure and conclusions. 2. ed. Oxford, Clarendon Press, 310p.

Michener, C.D. 1953. The biology of a leafcutter bee (Megachile brevis) and its associates. Univ. Kans. Sci. Bull. 35: 16591748 .

Michener, C.D. 1974. The social behavior of the bees: A comparative study. 2ed. Massachusetts, Harvard University Press, 404p.

Michener, C.D. 2000. The bees of the world. Baltimore, The John Hopkins University Press, 913p.

Michener, C.D., R.B. Lange, J.J. Bigarella \& R. Salamuni. 1958. Factors influencing the distribution of bees' nests in earth banks. Ecology 39: 208-217.

Michener, C.D. \& R.W. Brooks. 2003. Dispersal of brood cells in a Mesoamerican hylaeine bee: A probable risk-spreading behavior (Hymenoptera, Colletidae), p.151-152. In G.A.R. Melo \& I. Alves-dos-Santos (eds.), Apoidea Neotropica: Homenagem aos 90 anos de Jesus Santiago Moure. Criciúma, Editora UNESC, 320p.

Moorman, C.E., K.R. Russell, G.R. Sabin \& D.C. Guynn Jr. 1999. Snag dynamics and cavity occurrence in the South Carolina Piedmont. For. Ecol. Manage. 118: 37-48.

Morato, E.F. \& L.A.O. Campos. 2000a. Efeitos da fragmentação florestal sobre vespas e abelhas solitárias em uma área da Amazônia Central. Rev. Bras. Zool. 17: 429-444.

Morato, E.F. \& L.A.O. Campos. 2000b. Partição de recursos florais de espécies de Sida Linnaeus e Malvastrum coromandelianum (Linnaeus) Garcke (Malvaceae) entre Cephalurgus anomalus Moure \& Oliveira (Hymenoptera, Andrenidae, Panurginae) e Melissoptila cnecomala (Moure) (Hymenoptera, Apidae, Eucerini). Rev. Bras. Zool. 17: 705-727.

Newton, I. 1994. The role of nest sites in limiting the numbers of hole-nesting birds: A review. Biol. Conserv. 70: 265-276.

Nicolai, V. 1986. The bark of trees: Thermal properties, microclimate and fauna. Oecologia 69: 148-160.

Oliveira, M.L. de. 2001. Stingless bees (Meliponini) and orchid bees (Euglossini) in terra firme tropical forests and forest fragments, p.208-218. In R.O. Bierregaard, Jr., C. Gascon, T.E. Lovejoy \& R.C.G. Mesquita (eds.), Lessons from Amazonia: The ecology and conservation of a fragmented forest. New Haven, Yale University Press, 478p.

Oliveira, M.L., E.F. Morato \& M.V.B. Garcia. 1995. Diversidade de espécies e densidade de ninhos de abelhas sociais sem ferrão (Hymenoptera, Apidae, Meliponinae) em floresta de terra firme na Amazônia Central. Rev. Bras. Zool. 12: 13-24.

O’Neill, K.M. 2001. Solitary wasps: Behavior and natural history. Ithaca, Cornell University Press, 406p.

Paes, J.B., V. de M. Morais \& C.R. Lima. 2004. Resistência natural de nove madeiras do semi-árido brasileiro a fungos xilófagos em condições de laboratório. R. Árvore 28: 275-282.

Paetzel, M.M. 1973. Behavior of the male Trypoxylon rubrocinctum. Pan-Pac. Entomol. 49: 26-30.

Parker, F.D. 1986. Factors influencing mortality and nesting in managed populations of the sunflower leafcutter bee (Hymenoptera: Megachilidae). Environ. Entomol. 15: 877879.

Peruquetti, R.C. \& M.A. Del Lama. 2003a. Notas sobre a sociabilidade e a biologia de nidificação de Trypoxylon (Trypoxylon) asuncicola Strand, 1910 (Hymenoptera, Sphecidae). Rev. Bras. Entomol. 47: 297-301.

Peruquetti, R.C. \& M.A. Del Lama. 2003b. Alocação sexual e seleção sexo-dependente para tamanho de corpo em Trypoxylon rogenhoferi Kohl (Hymenoptera, Sphecidae). Rev. Bras. Entomol. 47: 581-588.

Pinard, M.A., F.E. Putz, D. Rumíz, R. Guzmán \& A. Jardim. 1999. Ecological characterization of tree species for guiding forest management decisions in seasonally dry forests in Lomerío, Bolivia. For. Ecol. Manage. 113: 201-213.

Potts, S.G. \& P. Willmer. 1997. Abiotic and biotic factors influencing nest-site selection by Halictus rubicundus, a ground-nesting halictine bee. Ecol. Entomol. 22: 319-328.

Price, P. W. 1984. Insect ecology. 2ed. New York, John Wiley \& Sons, $607 \mathrm{p}$.

Rau, P. 1932. The relation of the size of the cell to the sex of the wasp in Odynerus foraminatus Sauss. (Hymenopera: Vespidae). Entomol. News 43: 119-121.

Rau, P. \& N. Rau. 1970. Wasp studies afield. New York, Dover Publications, 372p.

Richards, O.W. 1934. The American species of the genus Trypoxylon. Trans. R. Entomol. Soc. Lond. 82: 173-360.

Rizzini, C.T. 1995. Árvores e madeiras úteis do Brasil: manual de dendrologia brasileira. São Paulo, Editora Edgard Blücher, 296p.

Roubik, D.W. 1989. Ecology and natural history of tropical bees. Cambridge, Cambridge University Press, 514p.

Roulston, T'Ai H. \& J.H. Cane. 2000. The effect of diet breadth and nesting ecology on body size variation in bees (Apiformes). J. Kansas Entomol. Soc. 73: 129-142.

Silveira, F.A. 2002. The bamboo-nesting carpenter bee, Xylocopa (Stenoxylocopa) artifex Smith (Hymenoptera: Apdiae), also nests in fibrous branches of Vellozia (Velloziacae). Lundiana 3: $57-60$.

Souza, M.H. 2002. Madeiras tropicais brasileiras. 2. ed. Brasília, IBAMA, 152p.

Spiering, D.J. \& R.L. Knight. 2005. Snag density and use by cavitynesting birds in managed stands of the Black Hills National Forest. For. Ecol. Manage. 214: 40-52.

Spradbery, J.P. 1973. Wasps: an account of the biology and natural history of solitary and social wasps. Seattle, University of Washington Press, 408p.

Strickler, K., V.L. Scott \& R.L. Fischer. 1996. Comparative nesting ecology of two sympatric leafcutting bees that differ in body 
size (Hymenoptera: Megachilidae). J. Kansas Entomol. Soc. 69: $26-44$.

Tepedino, V.J. \& F.D. Parker. 1986. Effect of rearing temperature on mortality, second-generation emergence, and size of adult in Megachile rotundata (Hymenoptera: Megachilidae). J. Econ. Entomol. 79: 974-977.

Tepedino, V.J. \& P.F. Torchio. 1989. Influence of nest hole selection on sex ratio and progeny size in Osmia lignaria propinqua (Hymenoptera: Megachilidae). Ann. Entomol. Soc. Am. 82: 355-360.

Tepedino, V.J. \& P.F. Torchio. 1994. Founding and usurping: Equally efficient paths to nesting success in Osmia lignaria propinqua (Hymenoptera: Megachilidae). Ann. Entomol. Soc. Am. 87: 946-953.

Thornhill, R. \& J. Alcock. 1983. The evolution of insect mating systems. Cambridge, Massachusetts, Harvard Univ. Press, $547 \mathrm{p}$.

Thorp, R.W., G.W. Frankie, J. Barthell, D. Gordon, L. Newstrom, T. Griswold, J. Schmidt \& S. Thoenes. 1992. Long-term studies to gauge effects of invading bees. Calif. Agric. 46: 20-23.

Trugilho, P.F. \& B.R. Vital. 1996. Correlação entre algumas características físicas, químicas e anatômicas e a variação dimensional da madeira de Eucalipto. R. Árvore 20: 515-533.

Viana, L.S. \& G.A.R. Melo. 1987. Conservação de abelhas. Inf. Agropec. 13: 23-27.

Vinson, S.B. \& G.W. Frankie. 1991. Nest variability in Centris aethyctera (Hymenoptera: Anthophoridae) in response to nesting site conditions. J. Kansas Entomol. Soc. 64: 156-162.

Vinson, S.B. \& G.W. Frankie. 2000. Nest selection, usurpation, and a function for the nest entrance plug of Centris bicornuta (Hymenoptera: Apidae). Ann. Entomol. Soc. Am. 93: 254-260.

Vinson, S.B., G.W. Frankie \& J. Barthell. 1993. Threats to the diversity of solitary bees in a Neotropical dry forest in Central America , p.53-81. In J. LaSalle \& I.D. Gauld (eds.), Hymenoptera and biodiversity. Wallingford, C.A.B. International, 348p.

Warren, T.L., M.G. Betts, A.W. Diamond \& G.J. Forbes. 2005. The influence of local habitat and landscape composition on cavity-nesting birds in a forested mosaic. For. Ecol. Manage. 214: $331-343$.

Wesserling, J. \& T. Tscharntke. 1995. Habitatwahl von bodennistenden Wildbienen und GrabwespenPflegemassnahmen im Experiment. Mitt. Dtsch. Ges. Allg. Angew. Entomol. 9: 697-701.

Westrich, P. 1996. Habitat requirements of central European bees and the problems of partial habitats, p.1-16. In A. Matheson, S.L. Buchmann, C. O’toole, P. Westrich \& I.H. Williams (eds.), The conservation of bees. London, Academic Press, 254p.

Wilson, E.O. 1971. The insect societies. Cambridge, Massachusetts, Belknap Press, 548p.

Wilson, E.O. 1975. Sociobiology: The new synthesis. Cambridge, Massachusetts, The Belknap Press, 697p.

Wuellner, C.T. 1999. Nest site preference and success in a gregarious, ground-nesting bee Dieunomia triangulifera. Ecol. Entomol. 24: 471-479.

Yanega, D. 1990. Philopatry and nest founding in a primitively social bee, Halictus rubicundus. Behav. Ecol. Sociobiol. 27: $37-42$.

Received 17/1/06. 